\title{
Effects of a Polymer-Coated Urea Product on Nitrogen Metabolism in Lactating Holstein Dairy Cattle
}

\author{
E. Galo*, S. M. Emanuele†, ${ }^{1}$, C. J. Sniffenł, J. H. White*, and J. R. Knapp* \\ *Department of Animal Science, \\ University of Vermont, \\ Burlington 05405 \\ †CPG Nutrients, Inc., \\ Syracuse, NY 13221 \\ ‡William H. Miner Institute, \\ Chazy, NY 12921
}

\begin{abstract}
The purpose of this study was to evaluate the impact of polymer-coated urea on nitrogen retention, rumen microbial growth, and milk production and composition. Coated urea (CU) that is more slowly hydrolyzed to ammonia than unprotected urea could potentially be used more efficiently by rumen microorganisms. Eight cows were offered each of three diets in a randomized crossover design. Each treatment period consisted of a 14-d adjustment period and a 5-d collection period. Diets were formulated to maintain milk production while reducing plasma urea nitrogen concentrations and urinary nitrogen excretion. Diets consisted of corn silage, mixed grass/legume haylage, chopped alfalfa hay, corn meal, protein, vitamin and mineral supplements, in a total mixed ration and fed ad libitum. The diets contained $17.9 \%, 18.1 \%$, and $16.4 \% \mathrm{CP}$ and 0 , $0.77 \%$, and $0.77 \% \mathrm{CU}$ (dry matter basis) and are denoted as CP18-CU, CP18+CU, and CP16+CU, respectively. Individual feed intakes were measured, and total fecal, and urine collections were conducted. Cows were milked twice daily at 0500 and $1700 \mathrm{~h}$, and the milk sampled for composition and milk urea $\mathrm{N}$ analysis. Dry matter intake averaged $23.5 \pm 0.2 \mathrm{~kg} / \mathrm{d}$ and was not altered by diet. Also, milk fat and true protein were not altered by diet and averaged 3.72 and $3.07 \%$, respectively. Milk yield was highest for diets CP18-CU and CP18+CU. Significant differences were observed in N intake and excretion in urine, feces, and milk between dietary treatments. Cows fed CP16+CU consumed $11 \%$ less $\mathrm{N}$ than in CP18-CU. Cows fed CP18+CU showed the highest excretion of $\mathrm{N}$ in urine, and together with $\mathrm{CP} 16+\mathrm{CU}$, the lowest $\mathrm{N}$ excretion in feces. Nitrogen excretion in milk was lower for cows fed CP16+CU.
\end{abstract}

Received July 9, 2002.

Accepted November 22, 2002.

Corresponding author: J. R. Knapp; e-mail: jknapp@zoo.uvm.edu.

${ }^{1}$ Current address: Land O'Lakes, Inc., Portage, Michigan 49002.
Calculated $\mathrm{N}$ balance was not significantly different between diets nor was it significantly different from zero. Efficiency of $\mathrm{N}$ capture in milk protein as a function of $\mathrm{N}$ intake was higher for animals on CP16+CU. Urinary excretion of purine derivatives was not different between diets, and estimated microbial $\mathrm{CP}$ was also similar. Coated urea was not effective at reducing nitrogen excretion by dairy cattle.

(Key words: coated urea, nitrogen metabolism, nitrogen balance, nitrogen excretion)

Abbreviation key: $\mathbf{C U}=$ coated urea, $\mathbf{D O M}=$ digestible organic matter, $\mathbf{M C P}=$ microbial crude protein, MUN = milk urea nitrogen.

\section{INTRODUCTION}

Nonprotein nitrogen can be used effectively as a source of nitrogen for the rumen microbes in diets for dairy and beef cattle. The amount of NPN that can be used is limited because of the rapid hydrolysis of the nitrogen in the NPN sources to ammonia in the rumen. This rapid breakdown to ammonia can occur at a much faster rate than ammonia utilization by the rumen bacteria, resulting in accumulation and escape of ammonia from the rumen (Satter and Roffler, 1975). The net result is that a potentially large part of the nitrogen from NPN sources is wasted and not utilized by rumen bacteria. Slow-release NPN compounds, which have been fed to ruminants, include isobutylidene diurea, acetylurea, biuret, starea, tung- and linseed-oil-coated urea and formaldehyde treated urea (Mudd, 1977; Tamminga and Hellemond, 1977; Miller, 1979; Owens et al., 1980;). These compounds have not been as advantageous as urea because a substantial part of the NPN in them may leave the rumen without being converted to ammonia, reducing its incorporation into microbial protein, and also because the ammonia formation from these compounds in the rumen, though slower than urea, was still too fast to optimize microbial protein 
Table 1. Ration ingredients (on DM basis) given as \% of total DM.

\begin{tabular}{|c|c|c|c|}
\hline Feedstuffs & CP18-CU & $\mathrm{CP} 18+\mathrm{CU}$ & $\mathrm{CP} 16+\mathrm{CU}$ \\
\hline Corn silage & 27.59 & 27.68 & 29.40 \\
\hline Grass/legume haylage & 15.70 & 15.76 & 15.76 \\
\hline Western alfalfa hay (chopped) & 6.79 & 6.81 & 6.82 \\
\hline Ground corn & 23.77 & 26.83 & 29.40 \\
\hline Soy hulls & 2.42 & 2.34 & 1.28 \\
\hline Wheat middlings & 0.00 & 5.11 & 2.64 \\
\hline Dried distiller's grains with solubles & 6.79 & 0.43 & 0.00 \\
\hline Canola meal & 4.24 & 0.00 & 0.00 \\
\hline Soybean meal, solvent extracted & 3.69 & 4.73 & 5.11 \\
\hline Corn gluten meal $60 \% \mathrm{CP}$ & 1.27 & 0.64 & 0.00 \\
\hline SoyPlus $^{1}$ & 2.55 & 3.32 & 3.41 \\
\hline Fish meal, menhaden & 0.55 & 0.72 & 0.43 \\
\hline Blood meal, porcine & 1.10 & 0.81 & 0.60 \\
\hline Urea & 0.30 & 0.13 & 0.09 \\
\hline Optigen $1200^{2}$ & 0.00 & 0.77 & 0.77 \\
\hline Molasses & 0.42 & 0.43 & 0.68 \\
\hline Megalac ${ }^{3}$ & 0.76 & 1.15 & 1.07 \\
\hline Limestone & 1.06 & 1.11 & 1.11 \\
\hline Salt & 0.38 & 0.38 & 0.38 \\
\hline Potassium magnesium sulfate & 0.25 & 0.34 & 0.38 \\
\hline Magnesium oxide & 0.17 & 0.17 & 0.17 \\
\hline Dicalcium phosphate & 0.08 & 0.26 & 0.34 \\
\hline Trace mineral mix & 0.04 & 0.04 & 0.04 \\
\hline Vitamin ADE mix & 0.04 & 0.04 & 0.04 \\
\hline Lysine $\mathrm{HCl}$ & 0.00 & 0.00 & 0.09 \\
\hline
\end{tabular}

\footnotetext{
${ }^{1}$ West Central Soy, Ralston, IA.

${ }^{2}$ CPG Nutrients, Syracuse, NY.

${ }^{3}$ Church \& Dwight, Princeton, NJ.
}

production by rumen bacteria (Owens and Zinn, 1988; Henning et al., 1993).

Because ammonia produced in the rumen is used for microbial growth, which is also dependent on energy availability, it is important that the rate of ammonia production in the rumen be coordinated with the rate of carbohydrate digestion. If the rates of rumen ammonia production and carbohydrate digestion are not synchronized, ammonia concentrations in the rumen will fluctuate after feeding (Newbold and Rust, 1992; Henning et al., 1993). It was hypothesized that coated urea (CU) would reduce nitrogen excretion in lactating Holstein dairy cattle by improving nitrogen utilization by rumen microbes without any adverse effects on DMI, milk production, and milk composition. To test this hypothesis, the objectives of this study were to evaluate the impact of feeding polymer-CU (Optigen 1200 Controlled Release Nitrogen; CPG Nutrients, Inc., Syracuse, NY) 1) on nitrogen excretion in urine, feces, milk, and calculated nitrogen balance, 2) rumen microbial crude protein (MCP) production, and 3) DMI, milk production, and milk composition.

\section{MATERIALS AND METHODS}

\section{Animals and Diets}

All animal procedures were approved by the University of Vermont Institutional Animal Care and Use
Committee. Eight multiparous lactating Holstein dairy cows ranging from 55 to 144 DIM were used for this experiment. Three dietary treatments were assigned to every cow in a randomized crossover design with three experimental periods. Diets contained either 0.0 or $0.77 \% \mathrm{DM}$ of $\mathrm{CU}$, respectively (Table 1). Coated urea was part of a concentrate mix provided by CPG Nutrients, Inc. The CU product used contained 97\% urea and $3 \%$ coating by weight. The forages used were corn silage, grass/legume haylage, and western alfalfa hay (Table 2). Diets were TMR mixed and fed two times a day at 0700 and $1600 \mathrm{~h}$ and offered ad libitum. All diets were formulated to be isoenergetic ( $1.76 \mathrm{Mcal}$ estimated $\mathrm{NE}_{\mathrm{L}}$ per kilogram DM; NRC, 1989). CP18-CU and $\mathrm{CP} 18+\mathrm{CU}$ were formulated to be isonitrogenous, and $\mathrm{CP} 16+\mathrm{CU}$ was formulated to contain more forage (55\% vs. 50\%) and have less nitrogen to test for efficiency of $\mathrm{N}$ utilization (Table 2).

\section{Experimental Period and Data Collection}

Each experimental period consisted of a total of 19 $\mathrm{d}$. The first $14 \mathrm{~d}$ were for adaptation to the diet and the last $5 \mathrm{~d}$ for sample collection. Cows were weighed at the beginning and end of each adaptation and collection period. For the adaptation period, cows were housed in a tie stall barn and milked twice daily at 0500 and 1700 h. Feed was weighed and offered twice daily at 0700 
Table 2. Chemical composition of the diets and forages.

\begin{tabular}{|c|c|c|c|c|c|c|}
\hline Nutrient (\% DM) & CP18-CU & $\mathrm{CP} 18+\mathrm{CU}$ & $\mathrm{CP} 16+\mathrm{CU}$ & Corn silage & $\begin{array}{l}\text { Grass/ } \\
\text { legume haylage }\end{array}$ & $\begin{array}{l}\text { Alfalfa } \\
\text { hay }\end{array}$ \\
\hline DM \% & 52.0 & 51.6 & 50.9 & 33.1 & 31.1 & 85.7 \\
\hline $\mathrm{CP} \%$ & 17.9 & 18.1 & 16.4 & 7.8 & 16.8 & 17.4 \\
\hline $\mathrm{NE}_{\mathrm{L}}(\mathrm{Mcal} / \mathrm{kg} \mathrm{DM})^{1}$ & 1.8 & 1.8 & 1.8 & 1.6 & 1.1 & 1.3 \\
\hline $\mathrm{NDF} \%$ & 35.9 & 35.5 & 34.2 & 43.7 & 62.2 & 45.9 \\
\hline $\mathrm{ADF} \%$ & 24.2 & 21.9 & 21.1 & 26.2 & 38.1 & 35.6 \\
\hline $\mathrm{NFC}^{2}$ & 35.2 & 35.5 & 38.9 & & & \\
\hline NSC & 30.4 & 32.4 & 34.8 & & & \\
\hline Starch \% & 26.9 & 29.0 & 31.4 & & & \\
\hline Sugar \% & 3.5 & 3.5 & 3.4 & & & \\
\hline Ether extract \% & 4.1 & 3.7 & 3.1 & & & \\
\hline Ash \% & 6.9 & 7.2 & 7.4 & & & \\
\hline
\end{tabular}

${ }^{1}$ Estimated using NRC, 1989.

${ }^{2} \mathrm{NFC}=$ Nonfiber carbohydrates.

and $1600 \mathrm{~h}$. Refusals were collected and weighed after the morning feeding for individual cows. This schedule was continued through the 5-d collection period, which was conducted in a separate room designed for total urine and fecal collection. Cows were moved into this room on $\mathrm{d} 12$ of the adaptation period and were allowed $2 \mathrm{~d}$ to adapt to the room before the 5 -d collection period started. Daily fecal and urine production were measured daily at $0800 \mathrm{~h}$ and recorded. Urine was collected through indwelling urinary catheters (28 French, 100 $\mathrm{ml}$ balloon, latex foley catheters; Harvet, Spring Valley, WI 54767) into containers acidified with $1 \mathrm{~L}$ of $6 \mathrm{~N}$ sulfuric acid to prevent ammonia from volatilizing. Feces $(5 \mathrm{~kg})$, urine $(150 \mathrm{ml})$, milk $(75 \mathrm{ml})$, feed $(5 \% \mathrm{wt} / \mathrm{wt})$ and refusals $(5 \% \mathrm{wt} / \mathrm{wt})$ were sampled each day from each cow and frozen.

\section{Laboratory Analyses}

Feces, feed, and refusals were dried for $24 \mathrm{~h}$ at $105^{\circ} \mathrm{C}$ in a forced-air oven to determine DM content. They were later ground with a Wiley mill through a $3-\mathrm{mm}$ screen. Feces, feed, and refusals were analyzed for CP using the Kjeldahl N methods (AOAC, 1990) at the University of Vermont and for ADF, NDF, lignin, ash, ether extract, NSC (AOAC, 1990), starch, and sugar content (Smith, 1969, as modified by Hall et al., 1999) at the West Virginia University Rumen Profiling Laboratory. Urinary $\mathrm{N}$ was also determined by Kjeldahl $\mathrm{N}$ methods. Milk composition was analyzed using near infrared spectrophotometry by the Vermont DHI laboratory. Milk urea N (MUN) and urine uric acid were determined using Sigma kits \#640 and 685 (Sigma Diagnostics, St. Louis, MO), respectively (Butler et al., 1996; Valladares et al., 1999). Urine allantoin was determined according to Chen and Gomes (1992).

\section{Nitrogen Balance Calculations}

Nitrogen balance (retention) was calculated as intake $\mathrm{N}$ - fecal $\mathrm{N}$ - urinary $\mathrm{N}$ - milk $\mathrm{N}$. Milk $\mathrm{N}$ was determined as milk true protein/6.38 plus milk urea and ammonia nitrogen content. MCP in $\mathrm{g} / \mathrm{d}$ was determined according to the following equation: $\mathrm{MCP}(\mathrm{g} / \mathrm{d})=3.99$ $\times 0.856 \times$ mmoles of purine derivatives excreted (Vagnoni et al., 1997).

\section{In Situ Determinations of Rumen Degradation Rates}

Two in situ studies were conducted to determine the rumen degradation of dietary components (Weakley et al., 1983). In the first study, protein degradation of dried and ground samples from the three experimental diets was measured. In the second study, protein and starch degradation of the concentrate mixes (not dried or ground) for each experimental diet was measured. In the first study, bags with $25-\mathrm{cm}^{2}$ surface area were used and filled with $2 \mathrm{~g}$ of sample each. In the second study the surface area of the bags used was $100 \mathrm{~cm}^{2}$, and each was filled with 5-g samples. The pore size for all bags was $50 \pm 15 \mu \mathrm{m}$. In both studies, two lactating Holstein dairy cows fitted with rumen cannulas were used. Duplicate bags for each of the three experimental diets were removed from the rumen after the times indicated below. The bags were immediately rinsed with cold water until the rinse water was clear. Bags were then dried for $24 \mathrm{~h}$ at $105^{\circ} \mathrm{C}$ in a forced-air oven and analyzed for $\mathrm{CP}$ and starch as above.

\section{In Vitro Urea Release}

An in vitro study was conducted to evaluate the rate of urea release from the CU product isolated from the concentrate mixes that had been used in the animal feeding experiments. Coated urea product obtained di- 
Table 3. Production and output variables, given as least squares means with pooled SE. Differing superscripts between diet means indicate significant differences $(P \leq 0.05)$.

\begin{tabular}{lcccc}
\hline & CP18-CU & CP18+CU & CP16+CU & SE \\
\hline DMI, kg/d & $23.6^{\mathrm{a}}$ & $23.6^{\mathrm{a}}$ & $23.1^{\mathrm{a}}$ & 0.23 \\
Milk yield, kg/d & $35.6^{\mathrm{a}}$ & $34.8^{\mathrm{ab}}$ & $33.8^{\mathrm{b}}$ & 0.44 \\
Milk fat, \% & $3.8^{\mathrm{a}}$ & $3.6^{\mathrm{a}}$ & $3.8^{\mathrm{a}}$ & 0.05 \\
Milk true protein, \% & $3.1^{\mathrm{a}}$ & $3.1^{\mathrm{a}}$ & $3.1^{\mathrm{a}}$ & 0.02 \\
Feces, kg of DM/d & $7.8^{\mathrm{a}}$ & $7.7^{\mathrm{ab}}$ & $7.3^{\mathrm{b}}$ & 0.11 \\
Urine, L/d & $23.2^{\mathrm{a}}$ & $25.2^{\mathrm{b}}$ & $22.8^{\mathrm{a}}$ & 0.42 \\
Milk/CP intake, kg/kg & $8.4^{\mathrm{a}}$ & $8.2^{\mathrm{a}}$ & $8.8^{\mathrm{b}}$ & 0.11 \\
\hline
\end{tabular}

rectly from the manufacturer was used as negative control, and uncoated urea was used as positive control. The samples (600 mg of each) were placed in separate beakers containing $100 \mathrm{ml}$ of $39^{\circ} \mathrm{C}$ distilled water and incubated at $39^{\circ} \mathrm{C}$ on a rocking platform at 24 oscillations per minute. The solutions were sampled $(10 \mu \mathrm{l})$ at the indicated times. The samples were analyzed for urea nitrogen using Sigma kit \#640.

\section{Statistical Analyses}

The mixed models procedure of SAS (Littell et al., 1996) was used for statistical analyses. The initial model used was an analysis of variance model with main effects for diet, period, and cow, with daily observations for a cow given as repeated measures within the period and all appropriate interactions. Interaction terms and period effects were tested and dropped from the model if they were not significant $(P>0.20)$. DIM was included as a covariate in the initial analysis for production and digestibility measurements. If it was not significant $(P>0.20)$, it was dropped from the model.

\section{RESULTS}

The diets did not affect milk fat percentage or milk true protein percentage (Table 3). Fat content of the milk approximated $3.7 \%$ across diets and is an indicator of good rumen fermentation and fiber digestion. Protein content of the milk was in agreement with Vermont's average milk protein percentage for the Holstein breed (3\%, Table 3). Milk production was lower for CP16+CU when compared to CP18-CU $(P \leq 0.05)$. DMI were similar for all diets and very close to initial predictions when formulating the diet $(23.5 \mathrm{~kg} \mathrm{DM})$. No disruptions in DMI were observed during the switch from the adaptation to the collection period.

Urine production was 2.0 and $2.4 \mathrm{~L} / \mathrm{d}$ higher for animals fed CP18+CU compared to CP18-CU and CP16+CU, respectively ( $P \leq 0.05$, Table 3$)$. The extra urine volume that was produced probably provided a vehicle for urinary nitrogen excretion, which was also higher for $\mathrm{CP} 18+\mathrm{CU}(P \leq 0.05$, Table 4$)$. Water consumption was not recorded for any of the diets.

Significant differences in $\mathrm{N}$ intake were achieved by diet formulation. Significant differences were observed in $\mathrm{N}$ excretion in urine, feces, and milk between diets (Table 4). Calculated $\mathrm{N}$ balance was not different between diets nor was it different from zero $(P>0.05)$. CP18+CU had the highest urinary $\mathrm{N}$ excretion of all diets. CP18-CU and CP16+CU did not differ in terms of urinary $\mathrm{N}$ excretion. MUN, in agreement with urinary nitrogen, was highest for CP18+CU $(P \leq 0.05)$, and was not different for diets CP18-CU and CP16+CU (Table 4). $\mathrm{CP} 18+\mathrm{CU}$ and $\mathrm{CP} 16+\mathrm{CU}$ had lower fecal $\mathrm{N}$ excretions than CP18-CU $(P \leq 0.05$, Table 4$)$.

Urinary excretion of allantoin was not affected by diet (Table 4). However, urine uric acid excretion levels did change across diets. Allantoin and uric acid were used to estimate the flow of MCP to the abomasum of the cows. Because allantoin is the major purine derivative, MCP production in the rumen was not different across diets and averaged $1.7 \mathrm{~kg} / \mathrm{d}$.

Animals fed CP16+CU were more efficient in terms of protein utilization (Table 3). They produced about $0.5 \mathrm{~kg}$ more milk for each kilogram of crude protein consumed. The efficiency of microbial crude protein production per unit of digested organic matter consumed was not affected by diet and averaged $112.7 \pm 2.6 \mathrm{~g}$ $\mathrm{CP}$ per kilogram of digestible organic matter (DOM) (Table 4).

Total tract apparent DM and CP digestibilities were higher for CP18+CU when compared to CP18-CU (Table 5). Apparent $\mathrm{ADF}$ digestibility was lower for both CP18+CU and CP16+CU (Table 5). Apparent digestibilities for other feed components (organic matter, NDF, starch, sugar, and NSC) did not differ across diets $(P$ $>0.05$ ).

To evaluate whether the different diets had resulted in different rumen availabilities of energy and nitrogen as a result of protein and starch degradation, two in situ studies were conducted. The rumen rate of degradation of dry matter in the total mixed rations of the three diets was similar when they had been dried and 
Table 4. Components of nitrogen balance, milk urea N, urinary excretion of purine derivatives, and estimated microbial CP flow from the rumen (MCP), given as least-squares means with pooled SE. Differing superscripts between diet means indicate significant differences $(P \leq 0.05)$.

\begin{tabular}{|c|c|c|c|c|}
\hline & CP18-CU & $\mathrm{CP} 18+\mathrm{CU}$ & $\mathrm{CP} 16+\mathrm{CU}$ & $\mathrm{SE}$ \\
\hline \multicolumn{5}{|l|}{$\mathrm{N}$ balance measures } \\
\hline $\mathrm{N}$ intake $(\mathrm{g} / \mathrm{d})$ & $683.4^{\mathrm{a}}$ & $687.9^{\mathrm{a}}$ & $614.8^{\mathrm{b}}$ & 8.12 \\
\hline$N$ in feces $(g / d)$ & $231.2^{\mathrm{a}}$ & $209.9^{\mathrm{b}}$ & $197.3^{\mathrm{b}}$ & 3.45 \\
\hline $\mathrm{N}$ in urine $(\mathrm{g} / \mathrm{d})$ & $259.9^{\mathrm{a}}$ & $302.2^{\mathrm{b}}$ & $245.4^{\mathrm{a}}$ & 5.08 \\
\hline $\mathrm{N}$ in milk $(\mathrm{g} / \mathrm{d})$ & $181.8^{\mathrm{a}}$ & $177.2^{\mathrm{ab}}$ & $171.8^{\mathrm{b}}$ & 2.16 \\
\hline $\mathrm{N}$ balance $(\mathrm{g} / \mathrm{d})$ & $11.1^{\mathrm{a}}$ & $-1.7^{\mathrm{a}}$ & $-0.3^{\mathrm{a}}$ & 6.35 \\
\hline Milk urea N (mg/dl) & $19.8^{\mathrm{a}}$ & $23.1^{b}$ & $19.8^{\mathrm{a}}$ & 0.40 \\
\hline \multicolumn{5}{|l|}{$\%$ of $\mathrm{N}$ intake in } \\
\hline Feces & $33.9^{\mathrm{a}}$ & $20.7^{\mathrm{b}}$ & $32.4^{\mathrm{ab}}$ & 0.43 \\
\hline Urine & $38.2^{\mathrm{a}}$ & $44.7^{\mathrm{b}}$ & $40.5^{\mathrm{a}}$ & 0.75 \\
\hline Milk & $25.5^{\mathrm{a}}$ & $25.8^{\mathrm{a}}$ & $28.0^{\mathrm{b}}$ & 0.27 \\
\hline \multicolumn{5}{|l|}{ Purine derivatives } \\
\hline Allantoin (mmoles/d) & $278.9^{\mathrm{a}}$ & $290.2^{\mathrm{a}}$ & $267.1^{\mathrm{a}}$ & 7.97 \\
\hline Uric acid (mmoles/d) & $87.4^{\mathrm{ab}}$ & $93.0^{\mathrm{a}}$ & $82.6^{\mathrm{b}}$ & 2.06 \\
\hline $\operatorname{MCP}(g / d)$ & $1706.1^{\mathrm{a}}$ & $1784.6^{\mathrm{a}}$ & $1631.5^{\mathrm{a}}$ & 41.01 \\
\hline Microbial CP (g)/digested OM (kg) & $112.4^{\mathrm{a}}$ & $115.8^{\mathrm{a}}$ & $110.8^{\mathrm{a}}$ & 2.59 \\
\hline
\end{tabular}

ground (Figure 1a). The only significant effect was due to time spent in the rumen. The effects of diet and individual cows were not significant. The rumen rate of crude protein degradation of the three diets was also similar, and time was the only significant factor (Figure $1 b)$. The rate of passage of a particular diet would be a major determinant of the extent of degradation of the $\mathrm{DM}$ and $\mathrm{CP}$ in the rumen. Thus, the in situ degradation or disappearance of the total mixed rations is not likely to be a complete indication of the potential degradation in vivo.

Rumen rates of degradation of DM and starch in the three concentrate mixes over time were not different $(P>0.05$; Table 6$)$. However, the rate of degradation of $\mathrm{CP}$ in the rumen was lower for $\mathrm{CP} 16+\mathrm{CU}$ when compared to the rates for the other two diets (Table 6). The intercepts represent the insoluble components (DM, $\mathrm{CP}$, or starch) that were not washed out during the initial rinse.

Preliminary data had indicated that the release rate of urea from the coated product should be approximately $20 \%$ of uncoated urea (S. M. Emanuele, unpub-

Table 5. Apparent total tract digestibilities, given as least squares means with pooled SE. Differing superscripts between diets means indicate significant differences $(P \leq 0.05)$.

\begin{tabular}{lllll}
\hline Digestibility (\%) & CP18-CU & CP18+CU & CP16+CU & SE \\
\hline DM & $65.9^{\mathrm{a}}$ & $69.3^{\mathrm{b}}$ & $67.6^{\mathrm{ab}}$ & 0.71 \\
OM & $68.4^{\mathrm{a}}$ & $69.2^{\mathrm{a}}$ & $70.0^{\mathrm{a}}$ & 0.72 \\
CP & $66.1^{\mathrm{a}}$ & $69.3^{\mathrm{b}}$ & $67.6^{\mathrm{ab}}$ & 0.60 \\
NDF & $48.8^{\mathrm{a}}$ & $49.9^{\mathrm{a}}$ & $47.5^{\mathrm{a}}$ & 1.11 \\
ADF & $49.2^{\mathrm{a}}$ & $44.2^{\mathrm{b}}$ & $43.2^{\mathrm{b}}$ & 1.45 \\
Starch & $88.2^{\mathrm{a}}$ & $88.8^{\mathrm{a}}$ & $88.1^{\mathrm{a}}$ & 1.02 \\
Sugar & $82.8^{\mathrm{a}}$ & $83.9^{\mathrm{a}}$ & $83.4^{\mathrm{a}}$ & 1.00 \\
NSC & $87.5^{\mathrm{a}}$ & $87.4^{\mathrm{a}}$ & $89.4^{\mathrm{a}}$ & 1.02 \\
\hline
\end{tabular}
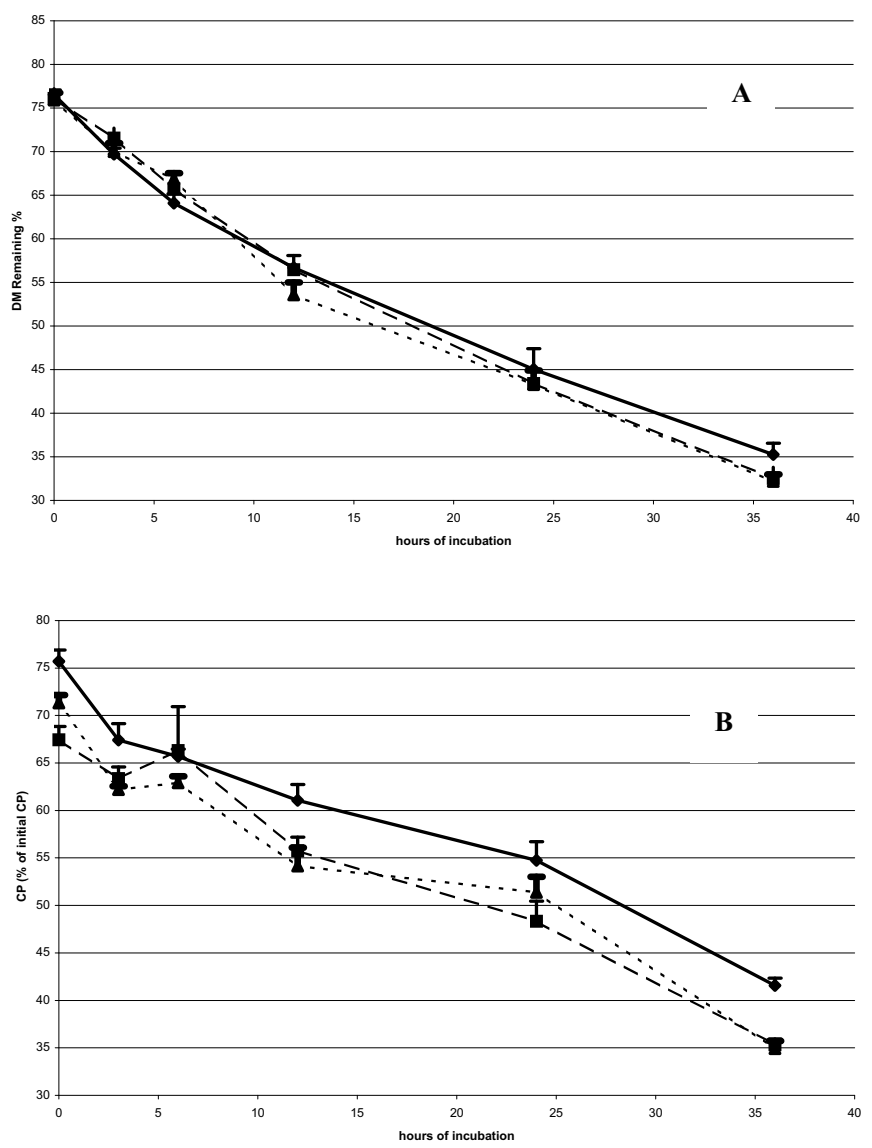

Figure 1. DM (A) and CP (B) disappearance (\% of initial) of dietary treatments at different times of incubation in the rumen of cattle. Data are given as means with vertical bars representing one standard

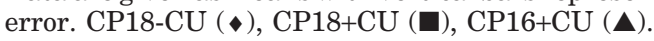


Table 6. Equation parameters for DM, CP, and starch degradation of concentrate mixes in the rumen as a linear function of time. Differing superscripts indicate significant differences between slopes for diets $(P$ $\leq 0.05$ ).

\begin{tabular}{lcccr}
\hline Parameter & CP18-CU & CP18+CU & CP16+CU & SE \\
\hline DM remaining & & & & \\
Intercept & 79.40 & 74.50 & 85.40 & 1.60 \\
Slope & 2.13 & 2.33 & 2.00 & 0.18 \\
CP remaining & & & & 70.00 \\
Intercept & 80.20 & 69.50 & $1.21^{\mathrm{b}}$ & 1.65 \\
Slope & $1.79^{\mathrm{a}}$ & $1.85^{\mathrm{a}}$ & & 0.16 \\
Starch remaining & & & & 102.70 \\
Intercept & 99.80 & 88.60 & 2.90 & 2.70 \\
Slope & 3.27 & 3.63 & & 0.30 \\
\hline
\end{tabular}

lished results). To evaluate whether the coating on the urea product had been damaged during mixing at the feed manufacturer, in delivery and unloading from storage, and/or during mixing into the TMR, rates of urea release were determined in vitro. Urea release from the CU used in the feeding experiment was $83 \%$ as extensive as uncoated urea after $1 \mathrm{~h}$ of incubation in water (Figure 2). The CU, which had not been mechanically handled, had released $67 \%$ as much urea as uncoated urea in $1 \mathrm{~h}$ (Figure 2). Both samples of CU released their urea rapidly in distilled water. Slower release rates into rumen fluid would be predicted (S. M. Emanuele, unpublished results). However, relative differences in release rates between CU samples would be expected to be the same.

\section{DISCUSSION}

Urinary nitrogen excretion was higher for CP18+CU when compared to the CP18-CU, which suggests that

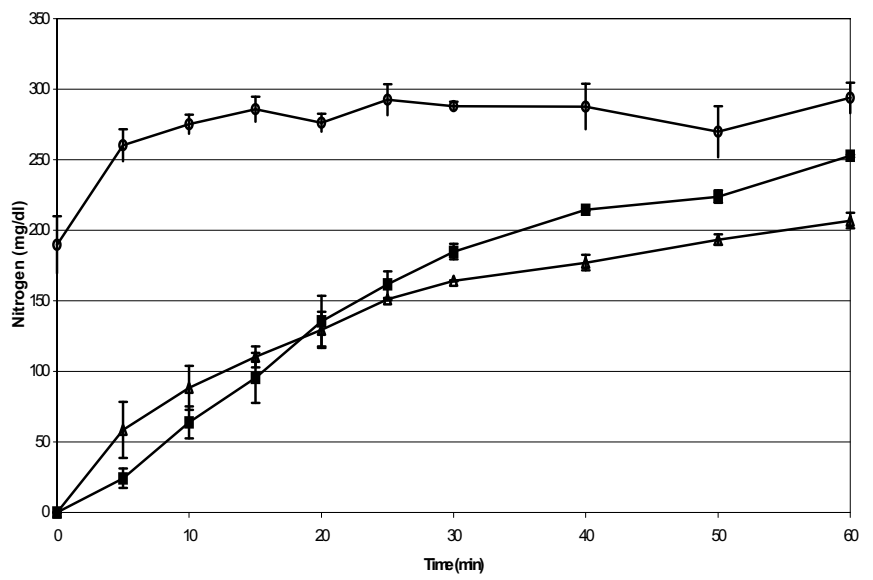

Figure 2. Urea release from polymer-coated products in vitro in distilled water compared to uncoated urea. Uncoated urea $(O)$, coated urea used in animal experiments ( $\mathbf{\square})$, and negative control-coated urea not mixed in diets $(\triangle)$ shown as means and standard errors of duplicate incubations. the nitrogen in $\mathrm{CU}$ was released more rapidly than expected $(6$ to $10 \mathrm{~h})$ and was not captured in MCP. This could have been due to damage of the polymer coating during feed mixing or transport. Cows fed urea at levels equivalent to those of CU in this study $(0.27 \mathrm{~g}$ urea per kilogram of BW) died due to ammonia toxicity within $2.5 \mathrm{~h}$ of feeding (Davis and Roberts, 1959). This suggests that if the coating had been completely destroyed, ammonia toxicity would have been likely to occur. No evidence of ammonia toxicity was observed in the current study. Increased urinary nitrogen excretion could also be a consequence of lower than expected rumen starch digestibilities across all diets, which would reduce MCP synthesis from CU.

Urine was the most prevalent route for excretion of nitrogen, followed by feces (Table 4). In a study by MacGregor et al. (1983), milk was the main route for nitrogen excretion, followed by feces. Urinary excretion of nitrogen will rise when there is ammonia accumulation in the rumen or high levels of deamination occurring in the body, due to excess protein fed or an unbalanced amino acid profile. MUN levels across diets corresponded to the urinary nitrogen levels, being higher for $\mathrm{CP} 18+\mathrm{CU}$ and similar for CP18-CU and CP16+CU (Table 4). The efficiency of nitrogen use for milk protein synthesis was not altered with the inclusion of $\mathrm{CU}$ in the diets (Figure 3). Nitrogen balance was similar for all diets and not different than zero (Table 4), suggesting that inclusion of CU did not alter whole animal nitrogen metabolism. Both urine N and MUN excretion are indicative of the blood urea levels, which in turn is indicative of the rumen ammonia levels.

One indicator of the efficiency of rumen nitrogen use is the amount of MCP flow from the rumen, which is a consequence of microbial growth and its washout from the rumen (Sniffen and Robinson, 1987). In this study, estimated MCP flow from the rumen was not different across diets and averaged $1707 \mathrm{~g} / \mathrm{d}$ (Table 4). MCP was also not different across diets when expressed in relation to DOM (113 g MCP per kilogram of DOM; Table 


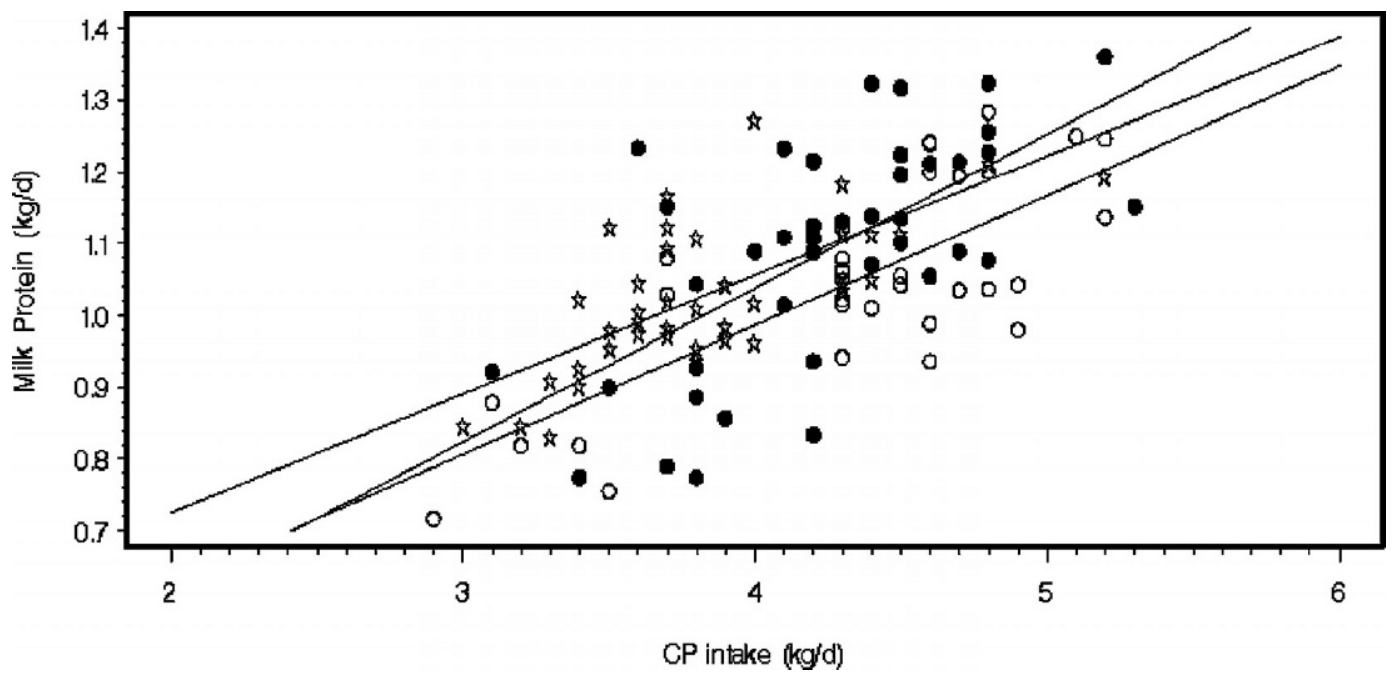

Figure 3. Milk protein as a function of crude protein intake. Each point represents one cow and one day. CP18-CU (๑), CP18+CU ( $)$, $\mathrm{CP} 16+\mathrm{CU}$ (放).

3). NRC (2001) predicts MCP yields of 150 to $225 \mathrm{~g}$ MCP per kilogram of DOM with ruminal $\mathrm{N}$ balances of +20 and $-20 \%$, respectively.

In a study by Timmermans et al. (2000), testing the effects of several dietary factors, MCP flow to the duodenum ranged from 765 to $1925 \mathrm{~g} / \mathrm{d}$, DMI ranged from 15.5 to $26 \mathrm{~kg} / \mathrm{d}$, and $\mathrm{N}$ intakes ranged from 428 to 832 $\mathrm{g} / \mathrm{d}$. Klusmeyer et al. (1990) fed cows two concentrations of nitrogen, $390 \mathrm{~g} / \mathrm{d}(11 \% \mathrm{CP})$ and $500 \mathrm{~g} / \mathrm{d}(14 \% \mathrm{CP})$ and found no changes in MCP flow from the rumen (2110 g MCP per day). Stokes et al. (1991) fed different levels of NSC and RDP to Holstein cows and found no differences in microbial efficiencies in terms of MCP/DOM; the average was $150 \mathrm{~g}$ MCP per kilogram of DOM. These authors did see a reduction $(-700 \mathrm{~g} / \mathrm{d})$ in $\mathrm{MCP}$ flow from the rumen for cows eating a diet low in NSC (24\%) and low in RDP (9\%).

Uric acid and allantoin comprised 24 and $76 \%$, respectively, of the purine derivatives found in urine across all diets in the current study. Similarly, Johnson et al. (1998) reported uric acid in urine representing 23.5\% of total purine derivatives excreted in urine of lactating cows. A very wide range of values (12 to $42 \%$ ) of uric acid excretion as a percentage of total purine derivatives in urine are reported in the literature (Lindberg and Murphy, 1991; Giesecke et al., 1994; Gonda and Lindberg, 1997; Vagnoni and Broderick, 1997; Vagnoni et al., 1997; Valladares et al., 1999).

Animals produced between 8.2 to $8.8 \mathrm{~kg}$ of milk for every kilogram of $\mathrm{CP}$ intake (Table 3 ). The highest efficiency was for $\mathrm{CP} 16+\mathrm{CU}$, while $\mathrm{CP} 18-\mathrm{CU}$ and $\mathrm{CP} 18+\mathrm{CU}$ did not differ statistically. CP16+CU had a higher NSC content and lower protein content than CP18-CU. The extra NSC may have allowed for more rumen ammonia to be captured and utilized by the rumen microbes, increasing its efficiency of conversion into milk. However, these efficiencies are lower than the 9 and 11.6 $\mathrm{kg}$ of milk per kilogram of CP intake reported when different sources of carbohydrates and proteins were fed (McCarthy et al., 1989).

Cows fed CP18+CU had higher apparent total-tract digestibilities of $\mathrm{CP}$ and DM compared to CP18-CU and lower ADF digestibility (Table 5). Cows on CP16+CU also had lower ADF digestibility than CP18-CU. Differences in nutrient digestibilities between diets may be due to the use of different feedstuffs across diets to achieve the desired chemical composition. Starch digestibility was not different across diets but was lower than expected ( $88 \%$ vs. 92 to $95 \%$ ). This could explain the lack of effects of CU inclusion in diets and also the reduced milk yield per kilogram of $\mathrm{CP}$ intake.

One possible explanation for the lack of response to feeding CU is that the release rate was more rapid than expected due to mechanical damage of the coating. In vitro release rates were very rapid (Figure 2). If $\mathrm{CU}$ was released faster than expected, then ammonia would accumulate at a time when energy was not yet available to the microbes, and ammonia would escape the rumen and end up being excreted as urea.

Rumen rates of starch degradation were not different across diets but were slower than expected (Figure 4). These rates approximate those observed for medium ground corn and were slower than the rates observed for fine ground corn by Callison et al. (2001, Figure 4). After $10 \mathrm{~h}$ of in situ incubation, the extent of starch degradation was 48,31 , and $25 \%$ for CP18+CU, CP18- 


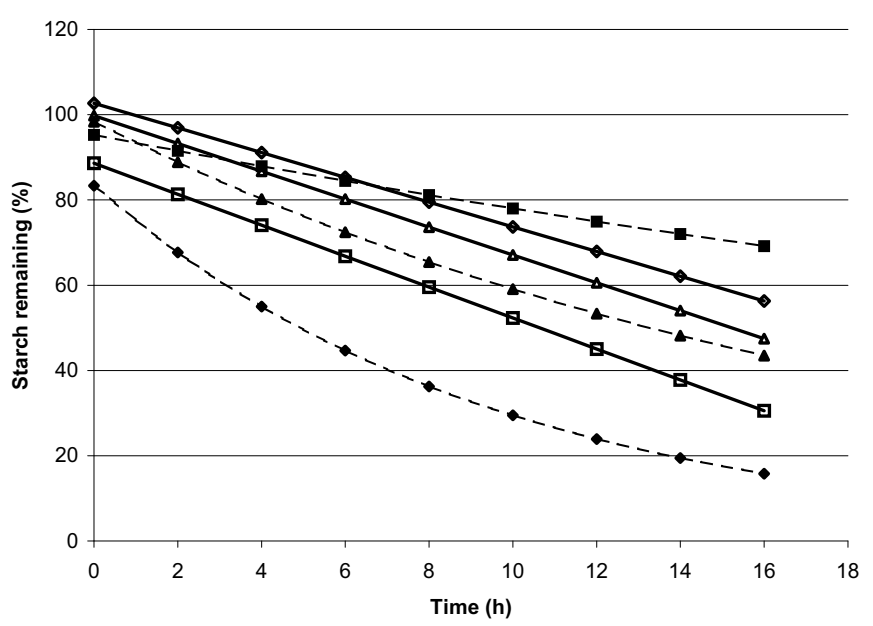

Figure 4. Rumen starch digestibilities of concentrate mixes compared to estimates calculated from degradation of corn meal differing in grind size (Calliston et al., 2001). CP18-CU $(\triangle)$, CP18+CU ( $\square$ ), $\mathrm{CP} 16+\mathrm{CU}(\diamond)$, fine ground corn meal $(\diamond)$, medium ground corn meal $(\mathbf{\Lambda})$, coarse ground corn meal $(\mathbf{\square})$.

$\mathrm{CU}$, and $\mathrm{CP} 16+\mathrm{CU}$, respectively. Consequently, energy may not have been available to the microbes at the time when ammonia from the CU was present.

\section{CONCLUSIONS}

Inclusion of coated urea did not affect DMI. Coated urea increased urinary $\mathrm{N}$ excretion in cows fed $\mathrm{CP} 18+\mathrm{CU}$. It also increased urinary $\mathrm{N}$ excretion in cows fed CP16+CU above what would have been expected from their reduced CP intake. These changes in urinary $\mathrm{N}$ excretion are paralleled by changes in MUN and lack of responses in MCP to dietary manipulation. The most likely explanations for these observations are either a partial breakdown of the polymer coating of coated urea and rapid release of the urea or a lower rumen starch digestibility than formulated, which affected microbial $\mathrm{N}$ utilization, or a combination of both. Urea was released at a faster rate in vitro than expected from the coated urea capsules, and starch was degraded slower than expected for all three diets, which supports the idea that a combination of both factors was responsible for the results obtained in this experiment in terms of $\mathrm{N}$ utilization by the animals. Improvements in these aspects may allow for similar approaches to increase efficiency of $\mathrm{N}$ utilization by ruminant animals.

\section{ACKNOWLEDGMENTS}

The assistance of the University of Vermont farm crew during the animal-feeding experiment and Erin Ramsay, Emilie Beaupré, and Kristin Steinman with sample preparation and laboratory analyses is greatly appreciated. Partial funding for this project was a gift from CPG Nutrients, Inc., Syracuse, NY.

\section{REFERENCES}

Association of Official Analytical Chemists. 1990. Official Methods of Analysis. 15th ed. AOAC, Arlington, VA.

Butler, W. R., J. J. Calaman, and S. W. Beam. 1996. Plasma and milk urea nitrogen in relation to pregnancy rate in lactating dairy cattle. J. Anim. Sci. 74:858-865.

Callison, S. L., J. L. Firkins, M. L. Eastridge, and B. L. Hull. 2001. Site of nutrient digestion by dairy cows fed corn of different particle sizes or steam rolled. J. Dairy Sci. 84:1458-1467.

Chen, X. B., and M. J. Gomes. 1992. Estimation of microbial protein supply to sheep and cattle based on urinary excretion of purine derivatives: an overview of technical details. Rowett Research Institute, Aberdeen, UK.

Davis, G. K., and H. F. Roberts. 1959. Univ. Florida Agr. Exp. Station Bulletin 611.

Giesecke, D., L. Ehrentreich, M. Stangassinger, and F. Ahrens. 1994. Mammary and renal excretion of purine metabolites in relation to energy intake and milk yield in dairy cows. J. Dairy Sci. 77:2376.

Gonda, H. L., and J. E. Lindberg. 1997. Effect of diet on milk allantoin and its relationship with urinary allantoin in dairy cows. J. Dairy Sci. 80:364.

Hall, M. B., W. H. Hoover, J. P. Jennings, and T. K. Miller Webster. 1999. A method for partitioning neutral detergent soluble carbohydrates. J. Sci. Food Agric. 79:2079-2086.

Henning, P. H., D. G. Steyn, and H. H. Meissner. 1993. Effect of synchronization of energy and nitrogen supply on rumen characteristics and microbial growth. J. Anim. Sci. 71:2516.

Johnson, L. M., J. H. Harrison, and R. E. Riley. 1998. Estimation of the flow of microbial nitrogen to the duodenum using urinary uric acid or allantoin. J. Dairy Sci. 81:2408.

Klusmeyer, T. H., R. D. McCarthy, Jr., J. H. Clark, and D. R. Nelson. 1990. Effects of source and amount of protein on rumen fermentation and passage of nutrients to the small intestine of lactating cows. J. Dairy Sci. 73:3526-3537.

Lindberg, J. E., and M. Murphy. 1991. Rumen metabolism, excretion of purine derivatives and milk composition in dairy cows fed rations with negative and positive protein balance values in the rumen. 6th Int. Symp. Protein Metab. Nutr., Herning, Denmark 2:336-338.

Littell, R. C., G. A. Milliken, W. W. Stroup, and R. D. Wolfinger. 1996. Page 633 in SAS System for Mixed Models. SAS Inst. Inc., Cary, NC

MacGregor, C. A., M. R. Stokes, W. H. Hoover, H. A. Leonard, L. L. J. Junkins, C. J. Sniffen, and R. W. Mailman. 1983. Effect of dietary concentration of total nonstructural carbohydrate on energy and nitrogen metabolism and milk production of dairy cows. J. Dairy Sci. 66: 39-50.

McCarthy, R. D., Jr., T. H. Klusmeyer, J. L. Vicini, J. H. Clark, and D. R. Nelson. (1989). Effects of source of protein and carbohydrate on rumen fermentation and passage of nutrients to the small intestine of lactating cows. J. Dairy Sci. 72:2002-2016.

Miller, W. J. 1979. The use of nonprotein nitrogen (NPN) for dairy cattle. Pages 62-73 in Dairy Cattle Feeding and Nutrition, T. J. Cunha, ed., Academic Press, New York.

Mudd, A. J. 1977. The use of nonprotein nitrogen in cattle diets. Pages 169-173 in Protein and Non-Protein Nitrogen for Ruminants. A Seminar of the United Nations Economic Commission for Europe, Pergamon Press, New York.

Newbold, J. R., and S. R. Rust. 1992. Effect of asynchronous nitrogen and energy supply on growth of rumen bacteria in batch culture. J. Anim. Sci. 70:538.

NRC, 1989. Nutrient Requirements of Dairy Cattle. 6th rev. ed. Natl. Acad. Sci. Washington, DC.

NRC, 2001. Nutrient Requirements of Dairy Cattle, 7 th rev. ed. Natl. Acad. Sci. Washington, DC. 
Owens, F. N., K. S. Lusby, K. Mizwicki, and O. Forero. 1980. Slow ammonia release from urea: rumen and metabolism studies. J. Anim. Sci. 50:527.

Owens, F. N., and R. A. Zinn. 1988. Protein metabolism of ruminant animnals. Page 227 in The Ruminant Animal, Digestive Physiology and Nutrition. D. C. Church, ed. Prentice Hall, Englewood Cliffs, New Jersey.

Satter, L. D., and R. E. Roffler. 1975. Nitrogen requirement and utilization in dairy cattle. J. Dairy Sci. 58:1219-1237.

Smith, D. 1969. Removing and analyzing total nonstructural carbohydrates from plant tissue. Wisconsin Agric. Exp. Station Research Report 41.

Sniffen, C. J., and P. H. Robinson. 1987. Protein and fiber digestion, passage, and utilization in lactating cows. Microbial growth and flow as influenced by dietary manipulations. J. Dairy Sci. 70:425-441.

Stokes, S. R., W. H. Hoover, T. K. Miller, and R. Blauweikel. 1991. Rumen digestion and microbial utilization of diets varying in type of carbohydrate and protein. J. Dairy Sci. 74: 871-881.

Tamminga, S., and K. K. van Hellemond. 1977. The protein requirements of dairy cattle and developments in the use of protein, essential amino acids and non-protein nitrogen in the feeding of dairy cattle. Pages 9-31 in Protein and Non-Protein Nitrogen for Ruminants. A Seminar of the United Nations Economic Commission for Europe, Pergamon Press, New York.

Timmermans, S. J. Jr., L. M. Johnson, J. H. Harrison, and D. Davidson. 2000. Estimation of the flow of microbial nitrogen to the duodenum using milk uric acid or allantoin. J. Dairy Sci. 83:1286.

Vagnoni, D. B., G. A. Broderick, M. K. Clayton, and R. D. Hatfield. 1997. Excretion of purine derivatives by holstein cows abomasally infused with incremental amounts of purines. J. Dairy Sci. 80:1695-1702.

Vagnoni, D. B., and G. A. Broderick. 1997. Effects of Supplementation of energy or rumenly undegraded protein to lactating cows fed alfalfa hay or silage. J. Dairy Sci. 80:1703-1712.

Valladares, R. F. D., G. A. Broderick, S. C. Valadares, and M. K. Clayton. 1999. Effect of replacing alfalfa silage with high moisture corn on rumen protein synthesis estimated from excretion of total purine derivatives. J. Dairy Sci. 82:2686-2696.

Weakley, D. C., M. D. Stern, and L. D. Satter. 1983. Factors affecting disappearance of feedstuffs from bags suspended in the rumen. J. Anim. Sci. 52 (2):493-507. 